\title{
Important Bird and Biodiversity Areas (IBAs): the development and characteristics of a global inventory of key sites for biodiversity
}

\author{
PAUL F. DONALD, LINCOLN D. C. FISHPOOL, ADEMOLA AJAGBE, \\ LEON A. BENNUN ${ }^{+}$, GILL BUNTING, IAN J. BURFIELD, \\ STUART H. M. BUTCHART, SOFIA CAPELLAN, MICHAEL J. CROSBY, \\ MARIA P. DIAS, DAVID DIAZ, MICHAEL I. EVANS, RICHARD GRIMMETT, \\ MELANIE HEATH, VICTORIA R. JONES, BENJAMIN G. LASCELLES, \\ JENNIFER C. MERRIMAN, MARK O'BRIEN, IVÁN RAMÍREZ, \\ ZOLTAN WALICZKY and DAVID C. WEGE
}

\section{Summary}

Important Bird and Biodiversity Areas (IBAs) are sites identified as being globally important for the conservation of bird populations on the basis of an internationally agreed set of criteria. We present the first review of the development and spread of the IBA concept since it was launched by BirdLife International (then ICBP) in 1979 and examine some of the characteristics of the resulting inventory. Over 13,00o global and regional IBAs have so far been identified and documented in terrestrial, freshwater and marine ecosystems in almost all of the world's countries and territories, making this the largest global network of sites of significance for biodiversity. IBAs have been identified using standardised, data-driven criteria that have been developed and applied at global and regional levels. These criteria capture multiple dimensions of a site's significance for avian biodiversity and relate to populations of globally threatened species $(68.6 \%$ of the 10,746 IBAs that meet global criteria), restricted-range species (25.4\%), biome-restricted species $(27.5 \%)$ and congregatory species (50.3\%); many global IBAs (52.7\%) trigger two or more of these criteria. IBAs range in size from $<1 \mathrm{~km}^{2}$ to over $300,000 \mathrm{~km}^{2}$ and have an approximately log-normal size distribution (median $=125.0 \mathrm{~km}^{2}$, mean $=1,202.6 \mathrm{~km}^{2}$ ). They cover approximately $6.7 \%$ of the terrestrial, $1.6 \%$ of the marine and $3.1 \%$ of the total surface area of the Earth. The launch in 2016 of the KBA Global Standard, which aims to identify, document and conserve sites that contribute to the global persistence of wider biodiversity, and whose criteria for site identification build on those developed for IBAs, is a logical evolution of the IBA concept. The role of IBAs in conservation planning, policy and practice is reviewed elsewhere. Future technical priorities for the IBA initiative include completion of the global inventory, particularly in the marine environment, keeping the dataset up to date, and improving the systematic monitoring of these sites.

\section{The evolution of the IBA concept}

Site-based conservation initiatives, such as protected area networks, form a major focus of conservation investment by governments, donors and civil society. Site protection can be effective in preventing or reducing habitat loss and other threats driving the biodiversity crisis (e.g. Beresford et al. 2013). However, biodiversity is very unevenly distributed around the planet, and can be highly concentrated in a relatively few small areas; for example, just $1 \%$ of the world's forest area 
supports $27 \%$ of the aggregate range-rarity (a measure that captures both species richness and endemism) of forest birds (Buchanan et al. 2011). There is evidence of a considerable mismatch between the distribution of biodiversity and the location of protected areas, which form one of the cornerstones of site-based responses to biodiversity loss (Rodrigues et al. 2004, Beresford et al. 2011, Butchart et al. 2012, 2015). There is therefore a clear need to identify the sites of greatest importance for biodiversity and to target conservation actions towards them.

The Important Bird Areas (IBA) programme (later changed to Important Bird and Biodiversity Areas when their importance for other taxa was demonstrated; see below) has its origins in legislation laid down by the European Economic Community (now the European Union) in the late 1970s. The 1979 Birds Directive (2009/147/EC) on the conservation of wild birds requires all Member States of the EU to take measures to conserve birds through the identification and designation of a network of special protection areas (SPAs), among other measures. At the time of its introduction, the Birds Directive highlighted a significant lack of understanding of where the most important sites for birds were and stimulated an effort to identify and document them. The IBA programme was therefore developed to guide the identification of areas of significance for birds in the EU, and so from the outset sought to delineate discrete sites that can be managed through conservation action. Their scale therefore differs from a number of subsequent approaches to identifying global priorities for conservation at a regional or landscape scale, such as Centres of Plant Diversity (WWF and IUCN 1994, 1995, 1997), the Global 200 Ecoregions (Olson and Dinerstein 1998), Endemic Bird Areas (Stattersfield et al. 1998) and Biodiversity Hotspots (Myers et al. 2000, Mittermeier et al. 2004). These broad-scale approaches are important for understanding the distribution of threatened biodiversity, for identifying priority regions and for promoting the more efficient allocation of geographically flexible conservation funding (Brooks et al. 2006) but offer less insight into targets for practical site-based actions.

For nearly 40 years, the IBA programme of BirdLife International has aimed to identify, document, safeguard, manage and monitor a network of sites of international significance for birds. This has created the globally most extensive site-based, spatially explicit, systematically rigorous biodiversity dataset yet compiled. The approach has inspired the development of similar protocols to identify key sites for other taxa, and these different approaches have recently been unified under the banner of Key Biodiversity Areas (KBAs; IUCN 2016), which can be viewed as a logical development of the IBA programme.

The recent publication of the KBA Standard and the renewed interest it has raised in the identification of important sites for biodiversity makes a review of the IBA programme particularly timely. We review for the first time the evolution of the IBA programme since its beginnings, covering the development of the IBA concept, the criteria by which IBAs are identified and the characteristics of the resulting inventory of sites. We also assess how IBAs function as a network, consider their provision of ecosystem services and reflect on the likely impacts of climate change and other threats on the functioning and future distribution of IBAs. The relevance and impact of the IBA programme in influencing conservation policy and practice, their role in systematic conservation planning and the important role of local conservation groups in conserving IBAs on the ground are discussed elsewhere (Waliczky et al. in press).

\section{History and coverage}

\section{Terrestrial and freshwater IBAs}

The IBA programme dates back to 1979, when the International Council for Bird Preservation (ICBP, now BirdLife International) and the International Waterfowl and Wetlands Research Bureau (IWRB, now Wetlands International) proposed to the Commission of the European Community that a study be undertaken to identify areas that might be considered under Article 4 of the newly adopted European Council Directive 79/409/EEC (the Birds Directive). A working 
group was established to oversee the development of the criteria by which such sites were to be identified and for the compilation of site-level data. The first output of this process was an inventory of 694 sites in the (then) nine Member States of the European Community (Osieck and Mörzer Bruyns, 1981). In the early 1980s, work with the EU Commission began to identify priority sites for the conservation of European migrant birds on their wintering grounds in Africa (Ledant et al. 1986). This study was the first to promote the idea that the IBA concept could be applied beyond Europe.

Further collaborative work between ICBP and IWRB resulted in the publication of a regional inventory of IBAs for Europe (Grimmett and Jones 1989), which expanded the European IBA network beyond the borders of the European Union. This milestone publication was a major step towards realising a continent-wide bird conservation strategy and accelerated progress towards maintaining and enhancing the conservation value of the sites it identified. In the same year, a separate inventory, commissioned by the European Commission, was published on IBAs in the (by then) 12 Member States of the European Community (Grimmett and Gammell 1989). With the publication of these inventories, national conservation organisations in many European countries began increasingly to focus their site conservation activities on national IBA networks, and local volunteers were mobilised at numerous IBAs to help protect, monitor and manage these sites.

In the early 1990s, the IBA programme was extended to the Middle East (Evans 1994) and then, following the creation of BirdLife International in 1993 and the development of standardised global IBA criteria, increasingly across the rest of the world (Table 1, Figs. 1, 2). The four global criteria (A criteria) are used to assess sites on the basis of the presence of globally threatened species (Criterion $A_{1}$ ), range-restricted species ( $\left.A_{2}\right)$, biome-restricted species $\left(A_{3}\right)$ and large congregations (A4). In 2000, a second inventory of European IBAs was published (Heath and Evans 2000), which contained 50\% more IBAs than the 1989 inventory. This substantial rise reflected the growing recognition of the importance of site-based inventories, the development and application of regional IBA criteria (B criteria) and criteria developed to guide conservation in the European Union ( $\mathrm{C}$ criteria), and increased knowledge of the distribution of biodiversity, which was largely a result of the stimulus provided by the first inventory. The break-up of the Soviet Union also led to greater participation by a larger number of states. Continent-wide IBA inventories of Africa (Fishpool and Evans 2001) and Asia (BirdLife International 2004a) followed shortly after, then inventories for Australia (Dutson et al. 2009) and most of the Pacific (BirdLife International 2010a). An IBA inventory of the five countries of the Tropical Andes (BirdLife International and Conservation International 2005) was soon followed by inventories of the Caribbean (BirdLife International 2008a) and the whole of the Americas (Devenish et al. 2009). IBA inventories have also been compiled for Palau, New Caledonia, Fiji, Antarctica and the UK and French Overseas Territories, among many others. The only major gap remaining in the coverage of terrestrial IBAs is New Guinea (both Papua New Guinea and West Papua). Thus, in a little over a decade, the identification of IBAs spread from Europe to most of the rest of the world, a remarkably rapid proliferation given the considerable resources required to undertake and publish IBA inventories. All of these inventories have been compiled using systematic criteria (see below), using data gathered locally by BirdLife Partners (national NGOs, generally one per country, that are part of the global BirdLife Partnership) or other organisations, and curated in a central database maintained by BirdLife International (http://www.birdlife.org/datazone/site/search). Published inventories have often taken the form of regional compendia, but the large size of these permits only the most basic data to be presented. Increasingly, IBA inventories have also been published in the form of national or even sub-national publications, which have the benefits of using local languages, allowing more detailed and more recent information to be presented, placing the set of sites within a conservation context at an appropriate scale and raising the profile of the organisations that produced them. A list of national and sub-national IBA inventories is available at: http:// www.birdlife.org/datazone/info/ibainventories. 
Table 1 . Summary of the number, area and protected area coverage of global and regional IBAs in 2017. Protected area coverage was assessed by a spatial intersection of IBA polygons with data in the World Database of Protected Areas (April 2017). IBA area was measured from polygons in GIS using a Behrmann equal-area projection; where polygons were not available (3.6\% of global IBAs, $1.6 \%$ of regional IBAs), the locallyentered estimate of IBA size was used instead. Note that 33 global IBAs (0.3\%) lack data on area and are excluded from the area statistics. Overseas territories are listed under their geographical region, not the region of their political affiliation. Marine IBAs falling within national jurisdictions are listed under their respective regions; those falling outside any national jurisdiction are shown separately under "High Seas"

\begin{tabular}{|c|c|c|c|c|c|c|}
\hline Region & No. IBAs & $\begin{array}{l}\text { Total area } \\
\left(\mathrm{km}^{2}\right)\end{array}$ & $\begin{array}{l}\text { Mean area } \\
\left(\mathrm{km}^{2}\right)\end{array}$ & $\begin{array}{l}\text { Median area } \\
\left(\mathrm{km}^{2}\right)\end{array}$ & $\begin{array}{l}\% \text { fully covered } \\
\text { by protected } \\
\text { areas }\end{array}$ & $\begin{array}{l}\text { Mean \% area } \\
\text { covered by } \\
\text { protected areas }\end{array}$ \\
\hline \multicolumn{7}{|l|}{ Global IBAs } \\
\hline Africa & 1,248 & $2,332,633$ & $1,885 \cdot 3$ & 176.9 & 26.7 & 50.3 \\
\hline Antarctica & 240 & 191,357 & $797 \cdot 3$ & 3.0 & 9.6 & $14 \cdot 3$ \\
\hline Asia & 2,392 & $2,702,302$ & $1,132.6$ & 138.0 & 16.1 & 40.6 \\
\hline Australasia & 499 & 465,434 & 936.1 & 71.0 & 28.9 & $53 \cdot 7$ \\
\hline Caribbean & 278 & 45,036 & 162.07 & 16.5 & 14.0 & $39 \cdot 7$ \\
\hline Central America & 155 & 170,757 & $1,101.7$ & 223.0 & 16.1 & $43 \cdot 7$ \\
\hline Central Asia & 410 & 415,427 & 1013.2 & 285.0 & $7 \cdot 5$ & 20.7 \\
\hline Europe & 2,630 & $1,155,916$ & 441.8 & 117.0 & 23.8 & 56.2 \\
\hline High Seas & 62 & $2,249,252$ & $36,278.3$ & $7,421.0$ & 0.0 & 0.0 \\
\hline Middle East & 311 & 231,907 & $745 \cdot 7$ & 118.0 & 17.0 & $29 \cdot 7$ \\
\hline North America & 1,030 & $1,627,349$ & $1,571.4$ & 218.0 & 9.9 & 31.0 \\
\hline Oceania & 209 & $1,317,152$ & $6,385.6$ & 30.0 & 12.7 & $24 \cdot 5$ \\
\hline South America & 1,282 & $2,400,271$ & $1,876.7$ & 244.0 & 16.1 & $39 \cdot 3$ \\
\hline All Global IBAs & 10,746 & $15,304,795$ & $1,427.9$ & 153.0 & 18.6 & 42.9 \\
\hline \multicolumn{7}{|l|}{ Regional IBAs* } \\
\hline Caribbean & 16 & 149 & 9.3 & 5.5 & 12.5 & 21.7 \\
\hline Europe & 2,346 & 460,005 & 196.2 & 53.1 & 33.0 & 74.6 \\
\hline Middle East & 85 & 58,555 & 688.9 & 48.0 & 8.9 & 20.1 \\
\hline All Regional IBAs & 2,447 & 518,708 & 212.2 & 51.6 & 32.1 & 72.4 \\
\hline All IBAs & 13,193 & $15,823,503$ & $1,202.6$ & 125.0 & 21.1 & 48.6 \\
\hline
\end{tabular}

* these totals exclude sites identified in North America (the USA and Canada) using national-level criteria.

\section{Marine IBAs}

Extending the terrestrial IBA programme to the marine environment was a logical and significant development, but one that posed conceptual and practical challenges, both in terms of data collection and in the application of the criteria in environments whose dominant features are often dynamic and poorly known (Hyrenbach et al. 2000). As a result, the global inventory of marine IBAs, particularly those located in offshore areas, is still in development. As with the terrestrial IBA programme, initial work on the identification of marine IBAs began in Europe, in response to the recognition that the European Union's Birds and Habitats Directives applied also to Member States' Exclusive Economic Zones (EEZs). The identification of marine IBAs began in the Baltic (Durinck et al. 1994, Skov et al. 2000) and the North Sea (Skov et al. 1995), followed by the Bering Sea (National Audubon Society 2004); these projects were, however, specific to the regions concerned and did not attempt to develop common approaches.

Subsequently, a process of standardisation was begun, stemming from an initial review by Osieck (2004). A follow-up analysis of existing IBA datasets (Howgate and Lascelles 2007) found that, across 158 countries and territories worldwide, some 2,000 IBAs had by that time been identified on the basis of their seabird populations, nearly all of which were in near-shore coastal waters. At the same time, a collaborative project involving BirdLife Partners in Portugal and Spain sought to identify marine IBAs within Iberian waters through the testing of different 


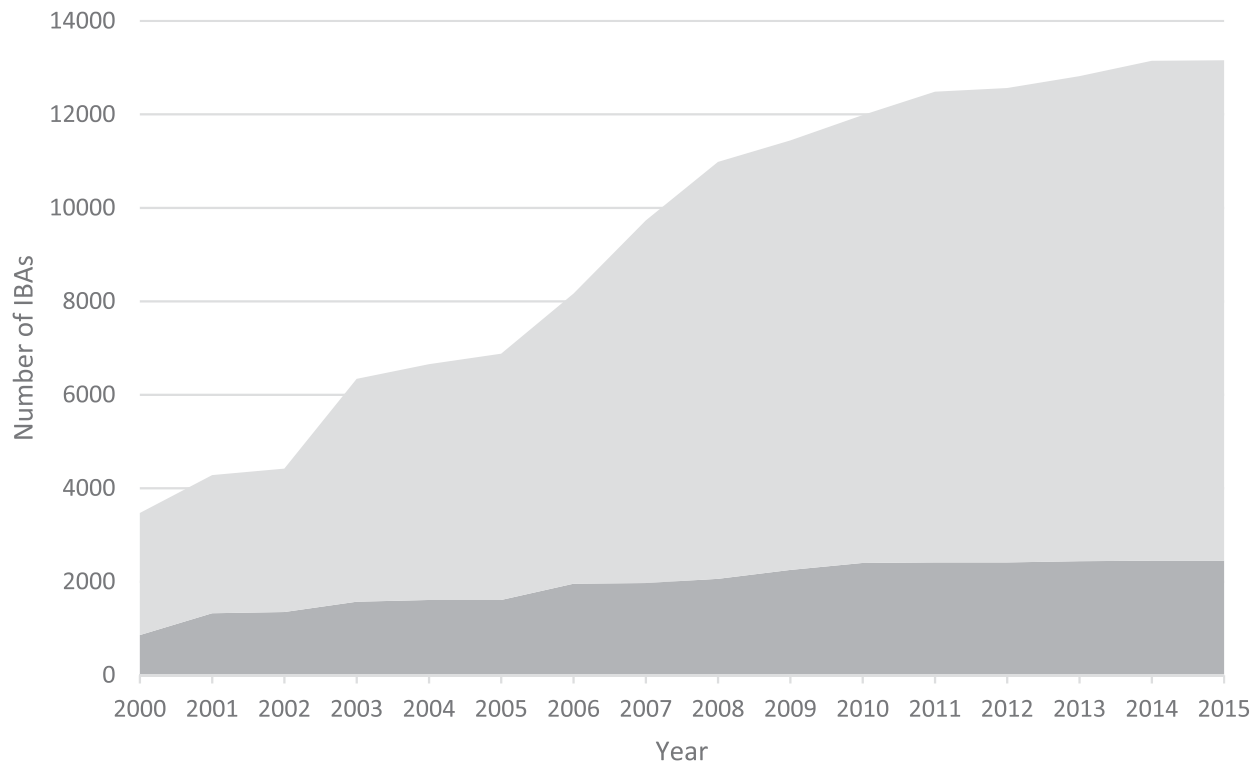

Figure 1. The increase in the number of IBAs, 2000-2015. Light grey: global IBAs, dark grey: regional IBAs. Regional criteria have been applied only in Europe, the Middle East and the Caribbean. These figures do not include sites identified in North America using national-level criteria similar to those used to identify IBAs.

data-collection and analytical approaches, resulting in the first repeatable methods of site selection in both coastal and pelagic waters (Ramírez et al. 2008, Arcos et al. 2009, Lascelles et al. 2012). There has been an increase in the number of BirdLife Partners engaged in marine IBA work, the focus of which has been within their respective national Exclusive Economic Zones (or equivalents). In 'Areas Beyond National Jurisdiction', the BirdLife Secretariat's Marine Programme leads the IBA identification process, which has drawn heavily upon analyses of seabird tracking data contributed by seabird researchers worldwide and held at www. seabirdtracking.org. Global standards for collecting, analysing and interpreting data from a range

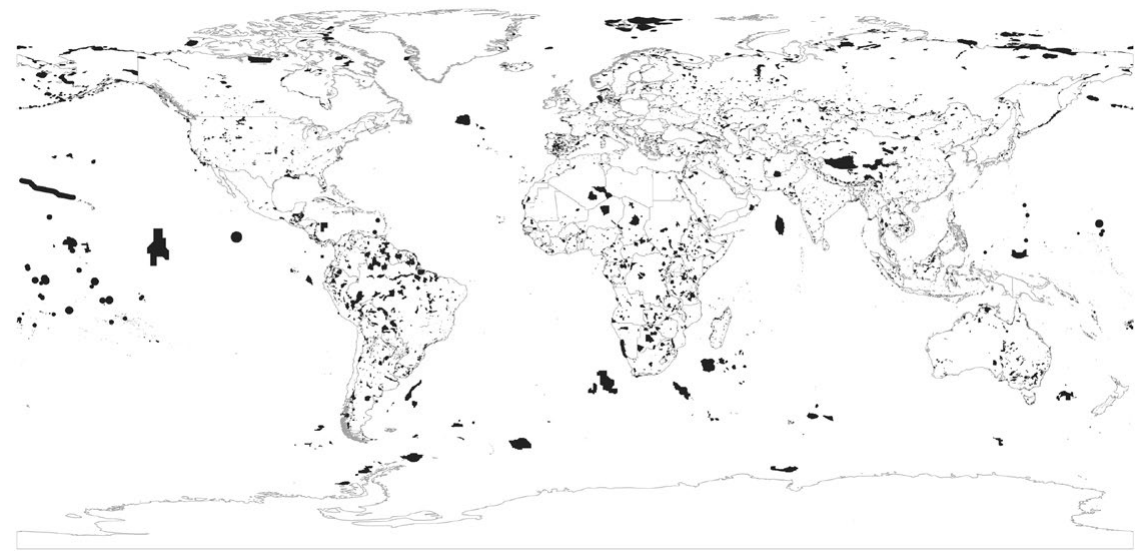

Figure 2. Distribution of the world's global IBAs in July 2017. 
of sources (e.g. satellite tracking, at-sea surveys, foraging preferences from literature reviews) to identify marine IBAs using the IBA criteria have now been developed (BirdLife International 2010b, Lascelles et al. 2016). To date, 2,621 IBAs have been identified for seabirds, of which 999 $(38 \%)$ include a significant marine component, and the remainder are essentially coastal or terrestrial (e.g. seabird breeding colonies).

\section{Regional IBAs}

In addition to the global IBAs described above, sites have been identified as IBAs using criteria and thresholds applicable at regional levels (Table 1 ). To date, this has been done most comprehensively in Europe, largely to ensure that IBA qualification complements European Union legislation. The set of 20 criteria used to identify sites of European (regional or 'B-level') and of European Union ('C-level') significance (Heath and Evans 20oo) were developed such that they nested within the global set as far as possible. For example, the regional criteria use regionally threatened species as triggers (thus shadowing global Criterion A1; Table 2), or lower thresholds for congregatory species (thus shadowing global Criterion $\mathrm{A}_{4}$ ). More recently, the value of regional IBAs has also been taken into account under the Bern Convention on the Conservation of European Wildlife and Natural Habitats, by governments required to designate sites as part of the Emerald Network, the de facto extension of the EU Natura 2000 network outside the EU, thereby contributing to the Pan-European Ecological Network.

Outside Europe, small numbers of regional IBAs have been identified in the Caribbean and in the Middle East using criteria similar, but not identical, to those used in Europe. Work is currently underway to produce a harmonised set of regional IBA criteria. A few countries, including the USA and Canada and Finland, have also identified important sites for birds at the national, state or local levels, in some cases using criteria developed especially for the purpose. While the identification of these sites may have substantial conservation value, in particular in countries that have the resources to conserve them effectively, only sites of international conservation significance are recognized as IBAs by the entire BirdLife International Partnership, in order to maintain the consistency of IBA designation.

\section{IBA criteria}

Key to the success of the IBA programme has been the development of standardised, datadriven criteria that are applied consistently across all countries worldwide. As the application of IBAs expanded beyond Europe, it became clear that the methods used to identify them needed to be modified to produce a set of criteria that could be globally applied to identify a unified set of sites of comparable significance for the conservation of birds. In the mid-199os considerable efforts were therefore devoted to refining and agreeing a set of simple, robust, semi-quantitative criteria of worldwide applicability (Bibby 1998, Fishpool et al. 1998, Bennun and Fishpool 2000). This set remained compatible with those used in Europe and the Middle East and drew heavily on the lessons learned there. The resulting IBA criteria and the thresholds used to identify them at the global level are summarised in Table 2. More detailed explanations of the criteria, and how they have been applied in different regions, can be found in Heath and Evans (2000), Fishpool and Evans (2001), BirdLife International (2004a, 2008a), BirdLife International and Conservation International (2005), and Devenish et al. (2009); see also http://datazone.birdlife.org/site/ibacriteria.

These categories and criteria have been designed to identify a network of sites for all bird species and assemblages of species for which a site-based approach is appropriate (Table 2) and have been used to identify IBAs worldwide in all environments in which wild birds occur. The considerable body of experience that has accrued in their use has led to minor modifications to some of the criteria (Table 2). All IBAs that were previously identified using species or thresholds now excluded by these revised criteria continue to qualify as regional IBAs. 
Table 2. A description of the four global IBA criteria. Most IBAs qualify under more than one criterion, as shown in Figure 4 .

\section{A2: Restricted range species}

Criterion: the site is known or thought to hold a significant component of the group of species whose breeding distributions define an Endemic Bird Area (EBA) or a Secondary Area (SA)

\section{Description}

The site qualifies if it is known, estimated or thought to hold a population of a species categorized on the IUCN Red List as globally threatened (Critically Endangered, Endangered or Vulnerable). The regular presence at a site of a Critically Endangered or Endangered species, irrespective of population size, may be sufficient to propose it as an IBA. Population-size thresholds for site selection for Vulnerable species are agreed regionally. The list of globally threatened species is maintained and updated annually for IUCN by BirdLife International (http://datazone.birdlife.org/species/search)

The site forms one of a set selected to ensure that, as far as possible, all the restricted-range species of an Endemic Bird Area (EBA) or Secondary Area (SA) are present in significant numbers in at least one site in the set and, preferably, more. Endemic Bird Areas are defined as places where two or more species of restricted-range, defined as those whose historical global breeding distributions are of smaller than 50,000 km², occur together (Stattersfield et al. 1998). A Secondary Area (SA) supports one or more restricted-range species, but does not qualify as an EBA because fewer than two species are entirely confined to it. For many EBAs that hold a large number of restricted-range species, a network of sites must be chosen to ensure adequate representation of all relevant species. Many EBAs cross political boundaries; where this is so, national networks of sites are selected to ensure that all relevant species in each country are adequately represented in IBAs. Thus, EBAs require that the network of sites take account of both the geographical spread of the EBA and the political boundaries that cross it, as appropriate. Seabirds were excluded by Stattersfield et al. (1998) from the EBA analysis, so this category is not applicable in the marine environment.
Previous versions of the criterion

Some regions previously allowed sites to be identified as global IBAs under this criterion on the basis of the presence of populations of 'other species of global conservation concern' (i.e. species listed on the IUCN Red List as Near Threatened or Data Deficient).

This option is no longer used so as to harmonise IBA

Criterion Aı with Criterion Aı of the KBA Standard. 
Table 2. Continued.

\begin{tabular}{|c|c|c|}
\hline IBA Criterion & Description & Previous versions of the criterion \\
\hline $\begin{array}{l}\text { A3: Biome-restricted assemblages } \\
\text { Criterion: the site is known or thought } \\
\text { to hold a significant component of the } \\
\text { group of species whose distributions are } \\
\text { largely or wholly confined to one biome }\end{array}$ & $\begin{array}{l}\text { The site forms one of a set selected to ensure that, as far as } \\
\text { possible, all species restricted to a biome are adequately } \\
\text { represented. Biome-restricted assemblages are groups of species } \\
\text { with largely shared distributions that occur mostly or entirely } \\
\text { within all or part of a particular biome. Many biomes hold large } \\
\text { numbers of species restricted to them, often across a variety of } \\
\text { different habitat types; networks of sites must be chosen to } \\
\text { ensure, as far as possible, adequate representation of all relevant } \\
\text { species. In data-poor areas, knowledge of the quality and } \\
\text { representativeness of the habitat types within sites alongside } \\
\text { incomplete knowledge of the presence of biome-restricted } \\
\text { species can be used to inform site selection. Many biomes cross } \\
\text { political boundaries; where this is so, national networks of sites } \\
\text { are selected to ensure that all relevant species in each country } \\
\text { are adequately represented in that country's IBAs. Thus, biomes } \\
\text { require that the networks of sites take account of both the } \\
\text { geographical spread of the biome and the political boundaries } \\
\text { that cross it, as appropriate. The biome approach, and therefore } \\
\text { the application of this category, has not yet been extended to the } \\
\text { marine environment. The biome category was not applied in } \\
\text { some island archipelagos that were comprehensively covered } \\
\text { by A2, e.g. Philippines, Wallacea, Greater and Lesser Antilles. } \\
\text { Biomes were determined on a regional basis using a range of } \\
\text { approaches; these approaches are currently being unified to } \\
\text { produce a standardised map of bird biomes. }\end{array}$ & \\
\hline
\end{tabular}

A3: Biome-restricted assemblages

to hold a significant component of the group of species whose distributions are largely or wholly confined to one biome represented. Biome-restricted assemblages are groups of species

with largely shared distributions that occur mostly or entirely

within all or part of a particular biome. Many biomes hold large

ensure, as far as possible, adequate representation of all relevan

species. In data-poor areas, knowledge of the quality and

political boundaries; where this is so, national networks of sites are selected to ensure that all relevant species in each country by A2, e.g. Philippines, Wallacea, Greater and Lesser Antilles. produce a standardised map of bird biomes. 
Table 2. Continued.

\begin{tabular}{|c|c|c|}
\hline IBA Criterion & Description & Previous versions of the criterion \\
\hline $\begin{array}{l}\text { A4: Congregations } \\
\text { Criterion: the site is known or thought } \\
\text { to hold congregations of } \geq_{1} \% \text { of the } \\
\text { global population of one or more species } \\
\text { on a regular or predictable basis. }\end{array}$ & $\begin{array}{l}\text { Sites can qualify whether thresholds are exceeded simultaneously } \\
\text { or cumulatively, within a limited period. In this way, the criterion } \\
\text { covers situations in which a rapid turnover of birds takes place } \\
\text { (e.g. migratory landbirds). Four previous sub-criteria (see next } \\
\text { column) were replaced by a single criterion that is congruent } \\
\text { with Criterion DI of the KBA Standard. }\end{array}$ & $\begin{array}{l}\text { Previously, four sub-criteria were used: } \\
\text { A4i: the site is known or thought to hold, on a regular } \\
\text { basis, } \geq 1 \% \text { of a biogeographic population of a } \\
\text { congregatory waterbird species. } \\
\text { A4ii: the site is known or thought to hold, on a regular } \\
\text { basis, } \geq 1 \% \text { of the global population of a congregatory } \\
\text { seabird or terrestrial species. } \\
\text { A4iii: the site is known or thought to hold, on a regular } \\
\text { basis, } \geq 20,000 \text { waterbirds or } \geq 10, \text { ooo pairs of seabirds } \\
\text { of one or more species. } \\
\text { A4iv: the site is known or thought to exceed thresholds } \\
\text { set for migratory species at bottleneck sites. } \\
\text { These sub-criteria created potential anomalies, because } \\
\text { A4i was based upon 'biogeographic' populations } \\
\text { (designed to align usage as closely as possible with } \\
\text { Ramsar criterion } 6 \text { ), while A4ii was based on global } \\
\text { populations. In addition, the thresholds used for criteria } \\
\text { A4iii and A4iv could be met by combinations of } \\
\text { multiple species, rendering their global significance } \\
\text { arguably lower than for sites holding more than } 1 \% \\
\text { of a global population of a single species. }\end{array}$ \\
\hline
\end{tabular}




\section{Applying IBA criteria in the marine environment}

Extending the IBA programme into the oceans necessitated a review of how to apply the IBA criteria in the marine realm. Following a review of relevant work within the European Union, Osieck (2004) concluded that, in addition to their breeding colonies, there were four aspects of seabird life-cycles potentially amenable to site-based conservation and to which the IBA criteria could therefore be applied: (i) seaward extensions of breeding colonies, (ii) non-breeding coastal concentrations, (iii) migratory bottlenecks and (iv) at-sea areas for pelagic species. This informed subsequent studies, which have shown that the IBA criteria were capable of capturing all life-cycle stages while recognising that, as with landbirds and waterbirds, a site-based approach to conservation is not appropriate for all species (Ramírez et al. 2008, Arcos et al. 2009, BirdLife International 201ob).

The increasing availability of seabird tracking data has created opportunities for identifying pelagic IBAs without the need to visit them, but applying criteria developed largely for terrestrial species to identifying key sites far from land on the basis of tracking data alone has proved challenging. Different researchers have deployed different tracking devices (light loggers, GPS loggers, satellite PTTs, etc.), which have variable spatial and temporal resolutions. Furthermore, the number of birds tracked from a particular colony typically represents a very small, and not necessarily representative, proportion of the total number present in that colony, so some extrapolation and caution are always necessary. However, sophisticated statistical methods have now been developed to improve the identification of important marine areas (Lascelles et al. 2016, Soanes et al. 2016), greatly increasing the potential to use standardised IBA criteria to identify key sites far from land.

\section{IBA boundary delineation}

Allied closely to the development of IBA criteria has been the process of IBA boundary delineation. As far as possible, IBA boundaries are identified such that: (i) the area inside the boundary is different in character, habitat or ornithological importance from surrounding areas; (ii) the IBA exists as a discrete manageable unit, such as a protected area, with or without buffer zones, and (iii) the site is an area that provides the requirements of the trigger species (i.e. those for which the site qualifies) while present, alone or in combination with networks of other sites. In many cases, delineation is straightforward, often dictated by obvious habitat boundaries or guided by existing protected area boundaries, land ownership or management boundaries. Other features that may be used in IBA delineation include roads or rivers, water catchment areas, local topographical features, contour lines, bathymetry, lines of longitude and latitude (particularly in the marine environment), measures of remoteness from settlements or roads (as indicators of intactness of habitat or lack of disturbance), boundaries of ownership or administration (e.g. legal or ethnic), logging concession data, and the geographical occurrence of actual and potential threat.

There is no set maximum or minimum size for an IBA, although the condition that the site forms a single manageable unit places a constraint on the maximum sensible area. In some cases, analysis of quantitative distributional data can help determine site size. A variety of approaches has also been taken on how to treat a number of small sites that are close to each other. Depending on the habitat requirements and management needs of the key species, the history of the landscape and the local situation, these could be considered as a series of individual small IBAs (assuming that each separately meets one or more of the selection criteria), a single IBA made up of several parts that are not joined to each other, or as a single larger site containing the key areas and the intervening land/water that may lack ornithological significance. Thus, discrete adjacent sites that have a long history of isolation and have different trigger species or communities might better be identified as separate IBAs, discrete adjacent sites that contain the same trigger species or communities might be better considered as a single IBA comprising several parts, and sites that contain populations of the same trigger species whose range boundaries are poorly defined might best be considered single IBAs within which it is acknowledged that there may be some unoccupied areas or unsuitable habitats. 


\section{Characteristics of the IBA network}

To date (April 2017), 10,746 global IBAs and 2,447 regional IBAs have been identified (Table 1). Around 2,00o additional national or sub-national (state-level) IBAs have been identified in North America, but the data on these have not yet been assessed against global or regional IBA criteria. The distribution of the sizes of IBAs is approximately log-normal (Fig. 3), so the mean is much larger than the median (Table 1 ). Most global IBAs are between $10 \mathrm{~km}^{2}$ and $1,000 \mathrm{~km}^{2}$ in area, with an overall median of $153 \mathrm{~km}^{2}$ and a mean of $1,427.9 \mathrm{~km}^{2}$. Sites range in size from less than $\mathrm{I} \mathrm{km}^{2}$ to over $300,000 \mathrm{~km}^{2}$. Significant differences within and across regions between both mean and median range sizes indicate the different biogeographical characteristics of the regions. For example, the very large mean size of IBAs in Oceania reflects the presence of some particularly extensive marine IBAs, whereas the small median size results from the fact that more than half the IBAs in the region are on small islands. The very small median size of IBAs in Antarctica is a reflection of the tendency of many of the qualifying species there, such as penguins (Spheniscidae), to breed in small, dense colonies on limited areas of ice-free land. Global IBAs are substantially larger than regional IBAs (Kruskall-Wallis test, $P<$ o.ooo1), at least partly because most regional IBAs are in Europe, where the mean size of IBAs is smaller than the global average due largely to the more fragmented nature of remaining natural habitats and thus the smaller size of conservation management units.

The frequency with which each of the four global criteria are met, as shown in Table 2, does not reveal the extent to which the different criteria are triggered together or independently. Around half of all global IBAs meet two or more criteria (Fig. 4). When considering only the three criteria that capture different elements of rarity or threat $\left(\mathrm{A}_{1}-\mathrm{A}_{3}\right)$, there is a greater coincidence between criteria $A_{1}$ and $A_{2}$ than of other pair-wise combinations, or their threeway intersection (Fig. 5). Even though Criterion $\mathrm{A}_{3}$ was not assessed for all IBAs, particularly those on small islands (Table 2), Criterion A2 is that which uniquely triggers fewest IBAs, since most sites meeting this criterion also meet other criteria. Over half of all IBAs meeting criterion AI are identified on the basis of the presence of a single qualifying ('trigger') globally threatened species (Fig. 6), although up to $1_{4}$ AI qualifying species have been recorded at a single site (Cuernos de Negros IBA, Philippines).

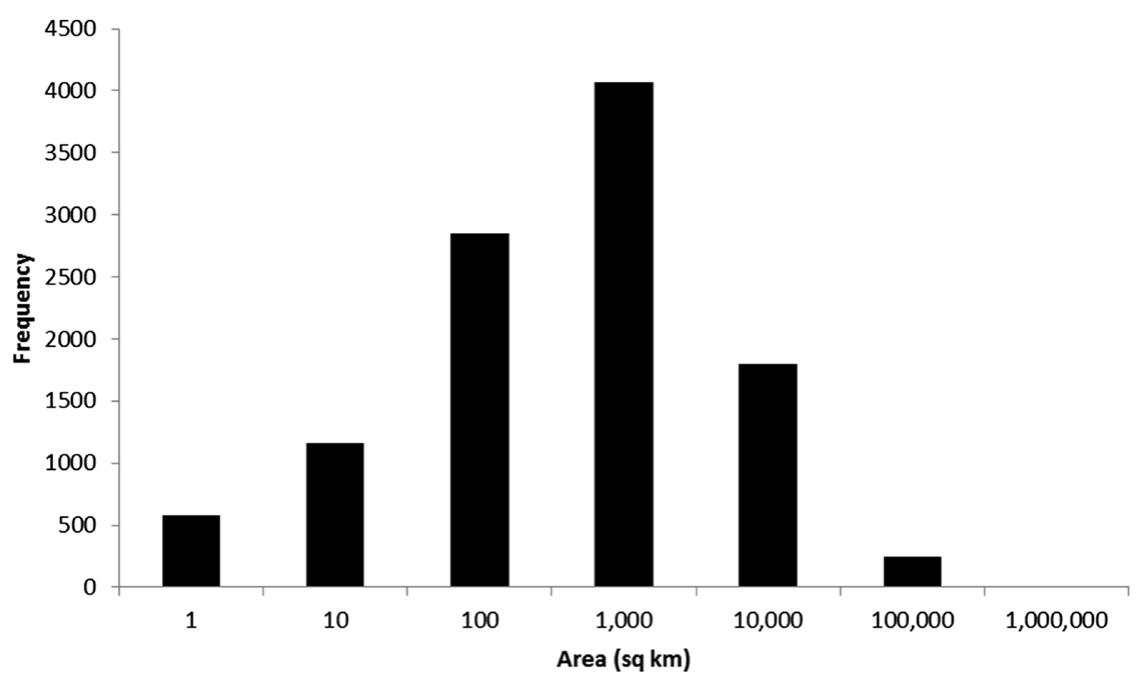

Figure 3. Frequency distribution of global IBAs of different sizes. Bin sizes are logarithmic, with the number on the $x$-axis representing the upper limit of each bin. 


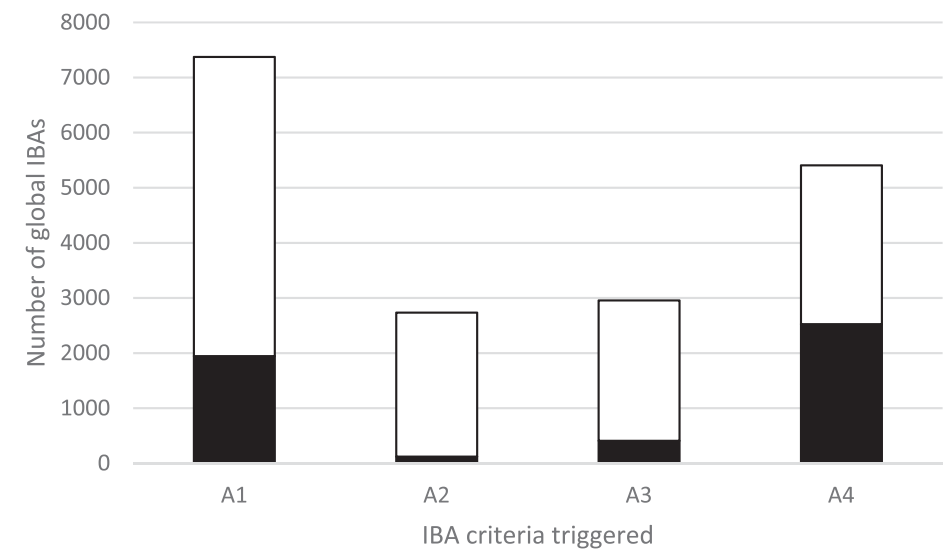

Figure 4. The number of IBAs qualifying under the four global IBA criteria (see Table 2). The shaded portion of each bar represents the number of IBAs that qualify solely under that criterion.

\section{Compiling a national IBA inventory}

The IBA identification process aims to locate, map and document all sites that are known or inferred to meet the selection criteria. Experience across many countries has demonstrated that there is no formulaic approach to compiling an IBA inventory, but some common patterns have emerged. The process entails a thorough review of existing knowledge of the national avifauna and its distribution, including analyses of IUCN Red List of Threatened Species data and data compiled for the identification of Endemic Bird Areas (Stattersfield et al. 1998), and consultations with experts and organisations that hold relevant data, such as Wetlands International, whose International Waterbird Census (IWC) data have informed IBA identification. This consultation may involve one or more national workshops that bring together experts and additional stakeholders to compile and discuss the draft IBA lists and undertake an initial gap analysis to ensure that relevant trigger species have not been omitted. These workshops also help publicise the

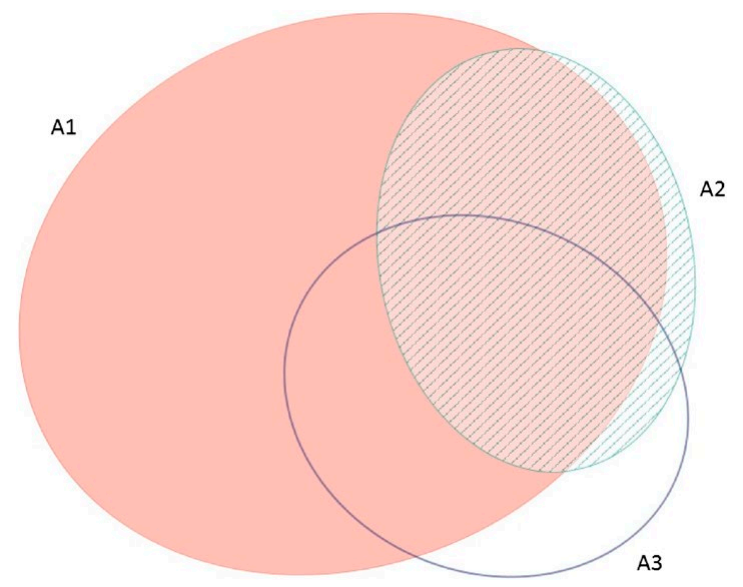

Figure 5. Venn diagram showing the proportion of IBAs meeting one, two or all three of the global IBA criteria relating to species extinction risk (AI), range restriction (A2) or biome restriction $\left(\mathrm{A}_{3}\right)$. Drawn using eulerAPE (Micallef and Rodgers 2014), which uses ellipses to allow exact area-proportional representation of all intersections. 


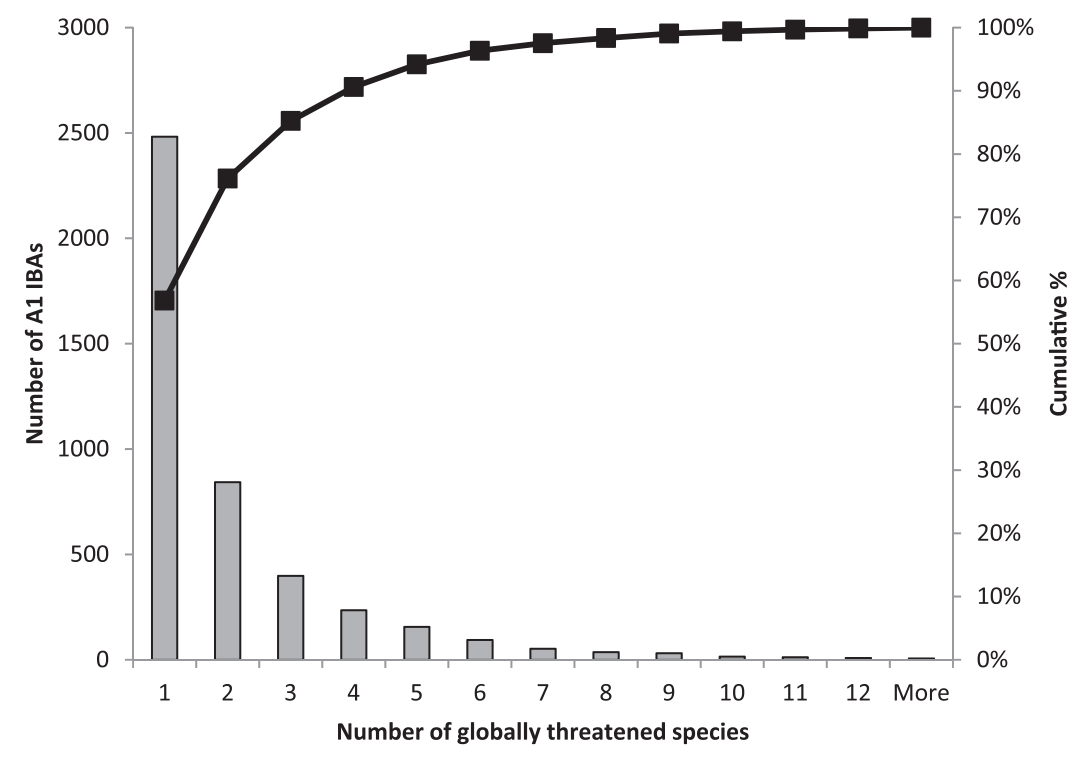

Figure 6. Histogram (with cumulative \%) of the number of qualifying species at IBAs meeting the global Ai criterion.

project, involve, train and enthuse participants, build national ownership of the IBA inventory, and ensure institutional buy-in to the results from the beginning. In some larger countries, existing national networks were mobilised, such as the Indian Bird Conservation Network and China Ornithological Society. This has had the incidental benefit of greatly strengthening the capacity of local conservation organisations to generate data relevant to conservation (Arinaitwe et al. 2007).

The output of this initial work is a list of potential IBAs, each of which usually falls into one of three broad categories: well-studied sites with adequate and up-to-date data, less well known sites with older or poorer quality information and, in some countries, areas for which there is little information but that are known or thought to hold good quality habitat in which IBA trigger species may be expected to occur. The first of these generally qualify as IBAs in the absence of any further ornithological data, while the second two represent gaps that require additional field work to determine whether or not they hold trigger species in numbers sufficient to meet IBA criteria. Where circumstances permit, surveys are then undertaken to fill in these gaps.

For those countries in which an in-depth approach to identifying an IBA network has not so far been possible (due to lack of resources, lack of a BirdLife Partner organisation or other appropriate body, political instability etc.), national inventories have been compiled by desk-based analyses that bring together all available information, relying on national expertise and input from nonBirdLife organisations. Other regional mechanisms have also been used, for example where there is ongoing species or habitat action planning. Some international agreements, such as the Bern Convention and its Emerald Network (Council of Europe 1979; https://www.coe.int/en/web/bernconvention/emerald-network), and some funding bodies, such as the Critical Ecosystem Partnership Fund (CEPF), invest resources in undertaking systematic site prioritisations before investment using methods similar to those used to identify IBAs.

In order to ensure that proposed IBAs from different countries meet a common standard, a final phase of confirmation is undertaken by the regional and global BirdLife Secretariats, which define lists of potential IBA-trigger species and thresholds, validate and confirm that proposals meet the criteria, and manage the database in which all IBA data are stored.

For all IBAs, data are collected not only on the trigger species present, but also location, physical characteristics, other (non-trigger) avifauna, habitats, land-use, threats, protection status, conservation 
activities, other significant non-avian biodiversity and literature sources. The methods used for compiling and classifying this information have been standardized as much as possible. Standard classifications have been developed for several of the data fields to simplify data collection and to facilitate subsequent comparisons and analyses. Further details are given in Heath and Evans (2000), Fishpool and Evans (2001), BirdLife International (2004a, 2008a), BirdLife International and Conservation International (2005) and Devenish et al. (2009).

\section{IBAs as networks}

As a consequence of their origins and the criteria used to identify them, IBAs have always been considered both as individual sites significant for the conservation of the populations they hold, and collectively as networks of sites. These, in different combinations, function to help secure regional populations, flyway populations of migratory species or indeed entire species. The network function of IBAs is particularly important for migratory species, whose use of IBAs varies seasonally. Many migratory birds follow well-defined flyways, along which they may congregate at certain stages of their annual cycle. IBA criteria allow identification of sites on the basis of migratory congregations and many species make use of different IBAs throughout their annual cycles. For many species, the need to minimise the length of crossings over water or other obstacles when moving between breeding and non-breeding areas results in concentrations at 'bottleneck' passage sites. A particular challenge to identifying such sites is that the number of birds present at any one time may represent only a small proportion of the total number of birds passing through the site each season.

Identification and analysis of site networks can help inform prioritisation of conservation action. As part of the collaborative 'Wings Over Wetlands' (WOW) African-Eurasian Flyways Project (http://wow.wetlands.org), the latest waterbird data held by BirdLife International and Wetlands International were compiled, combined with spatial data to allow population level analysis and assessed against two quantitative criteria (based on IBA and Ramsar criteria). In this way, 3,087 Critical Sites (all IBAs or sites that would meet IBA criteria) were identified for 559 populations of 244 species (Wings Over Wetlands 2011). Of these, 459 sites were identified for the first time as candidate IBAs on the basis of International Waterbird Census (IWC) data. Some Critical Sites met criteria for a single population, but many qualified for multiple populations and some sites supported more than 40 populations meeting the criteria. The WOW project demonstrates the value of reviewing site networks for particular taxonomic groups and geographic areas with a view to filling gaps in comprehensiveness, and to address gaps in protection and effective management.

IBA data also form the backbone of the Migratory Soaring Bird Sensitivity Mapping Tool (http:// migratorysoaringbirds.undp.birdlife.org/en/sensitivity-map), which focuses on wind energy development and combines data on soaring birds at IBAs with count data from other sources and satellite tracking data, then analyses and interprets it for a user-defined area in order to help developers, planning authorities and others to visualise and report on the relative sensitivity of different areas to potential wind energy development.

\section{IBAs, non-bird biodiversity and ecosystem services}

Birds are relatively easy to identify and record in the field and have relatively well-understood distributions and habitat requirements. As a result, more information is available on the status and distribution of the world's birds than for any other major taxonomic group (BirdLife International $2004 \mathrm{~b}, 2008 \mathrm{~b}$ ). A number of studies have shown that IBAs can be effective in capturing key sites or important populations of a wide range of other taxa, both on land (Pain et al. 2005, Tushabe et al. 2006, Butchart et al. 2012, 2015) and in the marine environment (Sydeman et al. 2007, Parsons et al. 2008, Lascelles et al. 2012, Butchart et al. 2015). Birds can therefore act as an indicator group for the identification of key sites for biodiversity conservation. For example, in five global biodiversity hotspots spanning 74 countries in which globally important sites (Key Biodiversity Areas) have also been systematically identified for mammals, amphibians and certain reptile, fish, plant and 
invertebrate clades, IBAs represent $68 \%$ of the number and cover $76 \%$ of the area of important sites for all these taxa (Butchart et al. 2012, BirdLife International 2014). In the European Union, IBAs cover $14 \%$ of the land area but capture a mean of $27.8 \%$ of the distributions of non-avian vertebrates, with coverage being highest for reptiles (34.5\%), followed by amphibians $(28.4 \%)$, and mammals (22.5\%; Kukkala et al. 2016). Because IBAs guide the designation of Special Protection Areas under EU law, the creation of Special Protection Areas for birds has resulted in the protection of sites of significance for other biodiversity (van der Sluis et al. 2016).

The IBA programme has been instrumental in inspiring and guiding the development of similar protocols to identify sites of importance to other taxa, such as Important Plant Areas (Plantlife 2010) and Prime Butterfly Areas (van Swaay \& Warren 2006). The proliferation of such initiatives led to a long process of research, trial and consultation to harmonise them and to include other elements of biodiversity not covered by existing approaches, resulting in the launch in 2016 of a Global Standard for the Identification of Key Biodiversity Areas (KBAs) (IUCN 2016). The criteria developed for the Global Standard owe much to those developed by BirdLife for the identification of IBAs (and, to a lesser extent, the opposite is also true; Table 2), and the KBA process can be seen as a logical extension of the IBA programme that began nearly 40 years ago. The recent establishment of a KBA Partnership, comprising 12 global conservation organisations and the launch of the World Database of Key Biodiversity Areas (www.keybiodiversityareas.org) is expected to add considerable impetus to efforts to identify and conserve a global network of sites of importance for all elements of biodiversity.

Sites significant for biodiversity conservation, including IBAs, deliver and support diverse ecosystem services that contribute to human well-being (Larsen et al. 2012). These include food production, provision of clean water, regulation of climate etc., as well as providing cultural, spiritual and recreational services (BirdLife International 2006a; Rands et al. 2010). An increasing number of IBAs have been the focus of studies to evaluate the ecosystem services they provide. The Toolkit for Ecosystem Service Site-based Assessment (TESSA; Peh et al. 2013) has been used in at least 40 IBAs to generate comparable estimates for the most likely alternative state of the IBA (e.g. after conversion to agriculture), so that the net consequences of land-use or policy decisions can be assessed. At Shivapuri-Nagarjun National Park in Nepal, for example, the net monetary benefit of protecting the site (compared with conversion to agriculture and urbanisation) was estimated to be at least $\$ 11$ million per year, with benefits accruing through greenhouse gas sequestration, carbon storage, nature-based recreation and improved water quality (Peh et al. 2016). At another Nepali IBA, Phulchoki Mountain Forest, the net economic value of the current community forestry management (compared with plausible alternative land-use) was at least $\$ 364,000$ per year, generated by benefits to water quality, greenhouse gas sequestration, harvested wild goods and nature-based recreation (Birch et al. 2014). In the Centre Hills Reserve IBA in Montserrat, a programme of hunting to control populations of feral livestock (and prevent ungulate-associated invasion by non-native plants) provides a net benefit of over $\$ 200,000$ per year generated from annual ecosystem service flows from nature-based recreation and harvested wild meat (Peh et al. 2014). At Yala Swamp IBA in Kenya, multiple ecosystem services were compared between two future alternative land use strategies (one of continued development and a balanced scenario where conservation and development coexist). The study demonstrated that adopting a balance between development and conservation would reduce agricultural potential but would improve the socio-economic well-being of local communities through better provision of harvested wild goods, water quantity and quality regulation. It would also reduce greenhouse gas emissions and provide higher recreation values while protecting the biodiversity that the site provides (Muoria et al. 2015). IBAs therefore support significant environmental benefits additional to the bird populations for which they are identified.

\section{IBAs and climate change}

A large number of studies have been published in recent years on the impacts of climate change on bird species (e.g. reviews in Pearce-Higgins and Green 2014, BirdLife International and National 
Audubon Society 2015). These studies predict that the distributions of many species will both move and shrink, meaning that there will be only partial overlap, or no overlap at all, between their current and future ranges. At the site level, therefore, there may be considerable turnover in community composition, and concerns have been raised about how useful IBAs and other static site-based approaches will prove under climate change (e.g. Coetzee et al. 2009). However, there is evidence that IBAs will remain important under projected climate change scenarios. For the sub-Saharan continental African IBA network, Hole et al. (2009) found that projected turnover in species varied regionally, but was substantial overall, with $10-13 \%$ median projected turnover across all IBAs for all species by 2025 , rising to $20-26 \%$ by 2085 . For priority (IBA 'trigger') species, turnover was projected to be $18-21 \%$ by 2025 , rising to $35-45 \%$ by 2085 . At $42 \%$ of IBAs, the turnover of priority species by 2085 was projected to exceed $50 \%$. However, IBAs projected to lose suitable climate space for the largest numbers of priority species are those projected to experience most new colonisations by priority species, as they are located in areas of high overall species turnover. Similar results were obtained for the IBA networks in the eastern Himalayas and the Lower Mekong; considerable turnover in species composition is expected, but the current network is not projected to lose all suitable climate space for any trigger species (Bagchi et al. 2013). These models are based solely on predicted movements in climate envelopes and do not consider any changes in habitat suitability at individual sites that might be brought about by climate change, but such models have been shown to be efficient in predicting changes in range and population (e.g. Fordham et al. 2017).

These results suggest that conserving IBAs can play a key role in mitigating the impacts of climate change, and that their conservation, including addressing other threats and ensuring adequate protection and appropriate management, remains a high priority (Hole et al. 2009, 2011).

\section{Targets for the future}

We identify three key targets in the future development of the IBA inventory and database, as part of the wider BirdLife IBA programme:

\section{Completing the marine IBA inventory}

The marine IBA inventory remains incomplete, not least in some areas due to political unwillingness (Ramírez et al. 2017), and it is likely that many marine IBAs await discovery and documentation. Understanding the distribution of seabirds using tracking technologies, and the development of suitable methods to identify the most important foraging hotspots and migratory bottlenecks from tracking data (Lascelles et al. 2016), have opened up new ways of delineating IBAs far from land, but the large number of seabird species and the huge number of (often widely dispersed) breeding colonies means that tracking alone is unlikely to identify all IBAs for all species. Efforts are now underway to narrow the search for new marine IBAs by combining existing tracking data with environmental data (such as sea surface temperature, plankton blooms, ocean eddies etc.) through statistical modelling to identify areas where conditions are likely to be particularly suitable for seabirds (e.g. Arcos et al. 2012, McDuie and Congdon 2016). Such analyses may reveal that important areas for seabirds vary greatly between years due to the dynamic nature of the marine environment, and a less static approach to site identification may need to be developed that is flexible to this stochasticity.

\section{Improving the monitoring of IBAs}

The identification of an IBA is just the first step in its conservation. It is then necessary to develop a system for tracking changes in the populations of its trigger species, their habitats, the threats they face and the conservation responses to those threats. BirdLife has developed a field-based protocol for monitoring IBAs using data on the state of the site and its key bird populations, pressure on the site resulting from threats and responses to those threats (BirdLife International 2006b). The protocol was designed to be simple and robust, so that it could be used by local conservation groups to generate data 
that are comparable across sites. Where this protocol has been applied systematically, it has proved effective in detecting change and stimulating action (Mwangi et al. 2010, Buchanan et al. 2013, Ndang'ang'a et al. 2016). However, field-based monitoring is costly in time and resources and is impractical in large, remote or hostile areas. The increasing availability of satellite imagery, and the development of tools to interpret such imagery in terms of conservation impact (Bastin et al. 2013), now permit more comprehensive assessment of some threats to IBAs and alert local conservationists to those threats. They also allow the generation of synthetic indices of the health of the IBA network globally (e.g. Buchanan et al. 2009a, Tracewski et al. 2016) to feed into processes such as the Convention on Biological Diversity (CBD)'s Aichi Targets (Butchart et al. 2012). However, while the most frequently reported threats to IBAs are those that can be detected remotely (Buchanan et al. 2009b), not all threats can be seen from space, and the population trends of most trigger species can only be weakly inferred. There is therefore an urgent need to expand in-situ monitoring to detect and track threats such as unsustainable exploitation and the impacts of alien invasive species, and to monitor the trends of the species for which a site qualifies as an IBA. This might be helped by the use of increasing volumes of citizen science data, generated by schemes such as eBird (Sullivan et al. 2014), BirdTrack (http://app.bto.org/birdtrack/main/data-home.jsp) and BirdLasser (https://www.birdlasser.com/), and of apps for smartphones, which can be used to collect spatially-referenced data that can be synchronised directly to central monitoring databases. However, significant difficulties remain in deriving reliable population trend estimates from such unstructured data (e.g. Kamp et al. 2016).

\section{Keeping the IBA inventory up to date}

In the same way that species can move between IUCN Red List categories as their conservation status changes, so sites can change over time in the number of IBA criteria they meet. For example, changes may arise through changes in the trigger species' conservation status, changes in taxonomy and changes in the populations of trigger species within KBAs, either real or due to improved knowledge (though it is usually impossible to distinguish between these). This can lead to new sites becoming eligible as IBAs under one or more of the existing criteria, or to current IBAs no longer qualifying under the criteria they previously triggered. This state of flux in the biodiversity that IBAs aim to capture represents a logistical challenge in maintaining an up-to-date and accurate inventory of thousands of sites in a rapidly changing world. It also raises a political challenge in balancing short-term changes in site status with the need to have a network of sites whose conservation may require longterm investment or advocacy. There is therefore a need to identify the optimal balance between frequency of site re-assessment and the stasis required for longer-term conservation processes to act.

\section{Acknowledgements}

We thank the many people who have contributed to the development of the IBA programme over the years, within the BirdLife Partnership and beyond. We are particularly grateful to Verónica Anadón-Irizarry, Julius Arinaitwe, Simba Chan, Rob Clay, Christian Devenish, Alistair Gammell, Eduard Osieck and Rudyanto. We thank Alison Stattersfield, Tammy Davies and Jez Bird for their inputs to this article. The IBA Programme has received sustained and generous support from Rio Tinto and from the Tasso Leventis Foundation. We are very grateful to Tom Brooks and three anonymous reviewers for very helpful comments on a previous version of this article.

\section{References}

Arcos, J. M., Bécares, J., Rodríguez, B. and Ruiz, A. (2009) Áreas importantes para la conservación de las aves marinas en España. Madrid, Spain: Sociedad Española de Ornitología (SEO/BirdLife).
Arcos, J. M., Bécares, J., Villero, D., Brotons, L., Rodríguez, B. and Ruiz, A. (2012) Assessing the location and stability of foraging hotspots for pelagic seabirds: An approach to identify marine Important 
Bird Areas (IBAs) in Spain. Biol. Conserv. 156: $30-42$.

Arinaitwe, J. A., Ngeh, P. C. and Thompson, H. S. (2007) The contribution of the Important Bird Areas programme to the conservation of birds in Africa. Ostrich 78 : 139-143.

Bagchi, R., Crosby, M., Huntley, B., Hole, D. G., Butchart, S. H. M., Collingham, Y., Kalra, M., Rajkumar, J., Rahmani, A., Pandey, M., Gurung, H., Trai, L. T., Van Quang, N. and Willis, S. G. (2013) Evaluating the effectiveness of conservation site networks under climate change: accounting for uncertainty. Glob. Change Biol. 19: 1236-1248.

Bastin, L., Buchanan, G. M., Beresford, A., Pekel, J. F. and Dubois, G. (2013) Opensource mapping and services for Web-based land-cover validation. Ecol. Informatics 14: 9-16.

Bennun, L. and Fishpool, L. (2000) The Important Bird Areas Programme in Africa: an outline. Ostrich 71: 150-153.

Beresford, A. E., Buchanan, G. M., Donald, P. F., Butchart, S. H. M., Fishpool, L. D. C. and Rondinini, C. (2011) Poor overlap between the distribution of protected areas and globally threatened birds in Africa. Anim. Conserv. 14: 99-107.

Beresford, A. E., Eshiamwata, G.W., Donald, P. F., Balmford, A., Bertzky, B., Brink, A. B., Fishpool, L. D. C., Mayaux, P., Phalan, B., Simonetti, D. and Buchanan, G. M. (2013) Protection reduces loss of natural land-cover at sites of conservation importance across Africa. PLoS ONE 8: e65370.

Bibby, C. J. (1998) Selecting areas for conservation. Pp. 176-201 in W. J. Sutherland, ed. Conservation science and action. Oxford, UK: Blackwell Science.

Birch, J. C., Thapa, I., Balmford, A. P., Bradbury, R. B., Brown, C., Butchart, S. H. M., Gurung, H., Hughes, F. M., Mulligan, M., Pandeya, B., Peh, K. S., Stattersfield, A. J., Walpole, M. and Thomas, D. H. (2014) What benefits do community forests provide, and to whom? A rapid assessment of ecosystem services from a Himalayan forest in Nepal. Ecosystem Services 8: 118-127.

BirdLife International (2004a) Important Bird Areas in Asia: key sites for conservation. Cambridge, UK: BirdLife International.
BirdLife International (2004b) State of the world's birds 2004: indicators for our changing world. Cambridge, UK: BirdLife International.

BirdLife International (2006a). Livelihoods and the environment at Important Bird Areas: listening to local voices. Cambridge, UK: BirdLife International.

BirdLife International (2006b) Monitoring Important Bird Areas: a global framework. Cambridge, UK: BirdLife International. Version 1.2. Available at http://datazone.birdlife.org/userfiles/ file/IBAs/Monitoring PDFs/IBA_ Monitoring_Framework.pdf

BirdLife International (2008b) State of the world's birds: indicators for our changing world. Cambridge, UK: BirdLife International.

BirdLife International (2008a) Important Bird Areas in the Caribbean: key sites for conservation. Cambridge, UK: BirdLife International.

BirdLife International (2010a) Important Bird Areas in the Pacific-a compendium. Suva, Fiji: BirdLife International.

BirdLife International (2010b) Marine Important Bird Areas toolkit: Standardised techniques for identifying priority sites for the conservation of seabirds at Sea. Cambridge, UK: BirdLife International.

BirdLife International (2014) Important Bird and Biodiversity Areas: a global network for conserving nature and benefiting people. Cambridge, UK: BirdLife International.

BirdLife International and Conservation International (2005) Áreas Importantes para la Conservacion de las Aves en los Andes Tropicales: sitios prioritarios para la conservacion de la biodiversidad. Quito, Ecuador: BirdLife International.

BirdLife International and National Audubon Society (2015) The messengers: what birds tell us about threats from climate change and solutions for nature and people. Cambridge, UK \& New York, USA: BirdLife International and National Audubon Society.

Brooks, T. M., Mittermeier, R. A., da Fonseca, G.A. B., Gerlach, J., Hoffmann, M., Lamoreux, J. F., Mittermeier, C. G., Pilgrim, J. D. \& Rodrigues, A. S. L. (2006) Global biodiversity conservation priorities. Science 313: 58-61. 
Buchanan, G. M., Nelson, A., Mayaux, P., Hartley, A. and Donald, P. F. (2009a) Delivering a global, terrestrial, biodiversity observation system through remote sensing. Conserv. Biol. 23: 499-502.

Buchanan, G. M., Donald, P. F., Fishpool, L. D. C., Arinaitwe, J. A., Balman, M. and Mayaux, P. (2009b) An assessment of land cover and threats in Important Bird Areas in Africa. Bird Conserv. Internatn. 19: 49-61.

Buchanan, G. M., Donald, P. F. and Butchart, S. H. M. (201I) Identifying priority areas for conservation: a global assessment for forestdependent birds. PLOS ONE 6: e29080.

Buchanan, G. M., Fishpool, L. D. C., Evans, M. I. and Butchart, S. H. M. (2013) Comparing field-based monitoring and remote-sensing, using deforestation from logging at Important Bird Areas as a case study. Biol. Conserv. 167: 334-338.

Butchart, S. H. M., Scharlemann, J. P. W., Evans, M., Quader, S. Arinaitwe, J., Bennun, L. A., Besançon, C., Boucher, T., Bomhard, B., Brooks, T. M., Burfield, I. J., Burgess, N. D., Clay, R. P., Crosby, M. J., Davidson, N. C. De Silva, N., Devenish, C., Dutson, G. C. L., Díaz Fernández, D. F., Fishpool, L. D. C., Foster, M., Hockings, M., Hoffmann, M., Knox, D., Larsen, F., Lamoreux,J.F.,Loucks, C., May, I., Millett, J. Parr, M., Skolnik, B., Upgren, A. and Woodley, S. (2012) Protecting important sites for biodiversity contributes to meeting global conservation targets. PLoS ONE 7: e32529.

Butchart, S. H. M., Clarke, M., Smith, B., Sykes, R., Scharlemann,J.P.W.,Harfoot,M., Buchanan, G. M., Angulo, A., Balmford, A., Bertzky, B., Brooks, T. M., Carpenter, K. E., Comeros, M., Cornell, J., Ficetola, G. F., Fishpool, L. D. C., Harwell, H., HiltonTaylor, C., Hoffmann, M., Joolia, A., Joppa, L., Kingston, N., May, I., Milam, A., Polidoro, B., Ralph, G., Richman, N., Rondinini, C., Skolnik, B., Spalding, M., Stuart, S. N., Symes, A., Taylor, J., Visconti, P. Watson, J. E. M. and Burgess, N. D. (2015) Shortfalls and solutions for meeting national and global protected area targets. Conserv. Lett. 8: 329-337.

Coetzee, B. W. T., Robertson, M. P., Erasmus, B. F. N., van Rensburg, B. J. and Thuiller, W. (2009) Ensemble models predict Important
Bird Areas in southern Africa will become less effective for conserving endemic birds under climate change. Global Ecol. Biogeogr. 18: 701-710.

Devenish, C., Fernández, D. F. D., Clay, R. P., Davidson, I. J. and Zabala, I. Y. (2009) Important Bird Areas Americas: priority sites for biodiversity conservation. Quito: BirdLife International.

Durinck, J., Skov, H., Jensen, F. P. and Pihl, S. (1994) Important marine areas for wintering birds in the Baltic Sea. Copenhagen: Ornis Consult.

Dutson, G., Garnett, S. and Gole, C. (2009) Australia's Important Bird Areas. Key sites for conservation. Birds Australia (RAOU) Conservation Statement No. 15.

Evans, M. I. (1994) Important Bird Areas in the Middle East. Cambridge UK: BirdLife International.

Fishpool, L. D. C. and Evans, M. I., eds. (2001) Important Bird Areas in Africa and associated islands: priority sites for conservation. Cambridge UK: BirdLife International.

Fishpool, L. D. C., Heath, M. F., Waliczky, Z., Wege, D. C. and Crosby, M. J. (1998) Important Bird Areas-criteria for selecting sites of global conservation significance. Ostrich 69: 428.

Fordham, D. A., Bertelsmeier, C., Brook, B. W., Early, R., Neto, D., Brown, S. C., Ollier, S. and Araújo, M. B. (2017) How complex should models be? Comparing correlative and mechanistic range dynamics models. Global Change Biol. DOI: https://doi.org/ 10.1111/gcb.13935.

Grimmett, R. F. A. and Gammell, A. B. (1989) Inventory of Important Bird Areas in the European Community. Unpublished report prepared for the Directorate-General for the Environment, Consumer Protection and Nuclear Safety of the European Community, Study contract B6610-54-88.

Grimmett, R. F. A. and Jones, T. A. (1989) Important Bird Areas in Europe. Cambridge, UK: International Council for Bird Preservation.

Heath, M. F. and Evans, M. I., eds. (200o) Important Bird Areas in Europe: priority sites for conservation. 2 vols. Cambridge UK: BirdLife International.

Hole, D. G., Huntley, B., Pain, D. J., Fishpool, L. D. C., Butchart, S. H. M., Collingham, 
Y. C., Rahbek, C. and Willis, S. G. (2009) Projected impacts of climate change on a continental-scale protected area network. Ecol. Letters 12: 420-431.

Hole, D. G., Huntley, B., Collingham, Y. C., Fishpool, L. D. C., Pain, D. J., Butchart, S. H. M. and Willis, S. G. (2011) Towards a management framework for protected area networks in the face of climate change. Conserv. Biol. 25: 305-315.

Howgate, E. and Lascelles, B. (2007) Candidate marine Important Bird Areas (IBAs): global status and progress. Cambridge, UK: BirdLife International, Unpublished report.

Hyrenbach, K. D., Forney, K. A. and Dayton, P. K. (2000) Marine protected areas and ocean basin management. Aquatic Conserv: Mar. Freshw. Ecosyst. 10: 437-458.

IUCN (2016) A Global standard for the identification of Key Biodiversity Areas, Version 1.o. Gland, Switzerland: IUCN.

Kamp, J., Oppel, S., Heldbjerg, H., Nyegaard, T. \& Donald, P. F. (2016) Unstructured citizen science data fail to detect long-term population declines of common birds in Denmark. Diversity Distrib. 22: 1024-1035.

Kukkala, A. S., Santangeli, A., Butchart, S. H. M., Maiorano, L., Ramírez, I., Burfield, I. J. and Moilanen, A. (2016) Representativeness of vertebrate species distributions in Important Bird and Biodiversity Areas and Special Protection Areas in the European Union. Biol. Conserv. 202: 1-9.

Larsen, F. W., Turner, W. R. and Brooks, T. M. (2012) Conserving critical sites for biodiversity provides disproportionate benefits to people. PLoS ONE 7: e36971.

Lascelles, B. G., Langham, G. M., Ronconi, R. A. and Reid, J. B. (2012) From hotspots to site protection: Identifying Marine Protected Areas for seabirds around the globe. Biol. Conserv. 156 (Special Issue 1): 5-14.

Lascelles, B. G., Taylor, P. R., Miller, M. G. R., Dias, M. P., Oppel, S., Torres, L., Hedd, A., Le Corre, M., Phillips, R. A., Shaffer, S. A., Weimerskirch, H. and Small, C. (2016) Applying global criteria to tracking data to define important areas for marine conservation. Diversity Distrib. 22: 422-431.

Ledant, J. P., Roux, F., Jarry, G., Gammell, A., Smit, C., Bairlein, F. and Wille, H. (1986) Aperçu des zones de grand intérêt pour la conservation des espèces d'oiseaux migrateurs de la Communautéen Afrique. European Commission, unpublished report. McDuie, F. and Congdon, B. C. (2016) Transequatorial migration and non-breeding habitat of tropical shearwaters: implications for modelling pelagic Important Bird Areas. Mar. Ecol. Progr. Ser. 550: 219-234.

Micallef, L. and Rodgers, P. (2014) eulerAPE: Drawing Area-Proportional 3-Venn Diagrams Using Ellipses. PLoS ONE 9: e101717.

Mittermeier, R. A., Gil, P. R., Hoffmnann, M., Pilgrim, J., Brooks, T., Mittermeier, C. G., Lamoreux, J. and Da Fonseca, G. A. B. (2004) Hotspots revisited: Earth's biologically richest and most endangered terrestrial ecoregions. Mexico City: Cemex.

Muoria, P., Field, R., Matiku, P., Munguti, S., Mateche, E., Shati, S. and Odeny, D. (2015) Yala Swamp Ecosystem Service assessment. Nairobi: Nature Kenya - the East Africa Natural History Society.

Mwangi, M. A. K., Butchart, S. H. M., Munyekene, F. B., Bennun, L.A., Evans, M. I., Fishpool, L. D. C., Kanyanya, E., Machekele, J., Matiku, P., Mulwa, R., Ngari, A., Siele, J. and Stattersfield, A. J. (2010) Tracking trends in key sites for biodiversity: a case study using Important Bird Areas in Kenya. Bird Conserv. Internatn. 20: 215-230.

Myers, N., Mittermeier, R.A., Mittermeier, C. G., da Fonseca, G. A. B. and Kent, J. (2000) Biodiversity hotspots for conservation priorities. Nature 403: 853-858.

National Audubon Society (2004) Important Bird Areas of the Bering Sea Ecoregion. New York, USA: National Audubon Society. Ndang'ang'a, P. K., Barasa, F. M., Kariuki, M. N. and Muoria, P. (2016) Trends in forest condition, threats and conservation action as derived from participatory monitoring in coastal Kenya. African J. Ecol. 54: 76-86.

Olson, D. M. and Dinerstein, E. (1998) The Global 200: a representation approach to conserving the Earth's most biologically valuable ecoregions. Conserv. Biol. 12: 502-515.

Osieck, E. (2004) Towards the identification of marine IBAs in the EU: an exploration by the Birds and Habitat Directives Task Force. Cambridge, UK: BirdLife International.

Osieck, E. R. and Mörzer Bruyns, M. F. (1981) Important bird areas in the European 
Community. Cambridge, UK: International Council for Bird Preservation.

Pain, D. J., Fishpool, L., Byaruhanga, A., Arinaitwe, J. and Balmford, A. (2005) Biodiversity representation in Uganda's forest IBAs. Biol. Conserv. 125: 133-138.

Parsons, M., Mitchell, I., Butler, A., Ratcliffe, N., Frederiksen, M., Foster, S. and Reid, J. B. (2008) Seabirds as indicators of the marine environment. ICES J. Mar. Sci. 65: 1520-1526.

Pearce-Higgins, J. W. and Green, R. E. (2014) Birds and climate change: impacts and conservation responses. Cambridge, UK: Cambridge University Press.

Peh, K. S.-H., Balmford, A., Bradbury, R. B., Brown, C., Butchart, S. H. M., Hughes, F. M. R., Stattersfield, A. J., Thomas, D. H. L., Walpole, M., Bayliss, J., Gowing, G., Jones, J.P.G., Lewis, S. L., Mulligan, M., Pandeya, B., Stratford, C., Thompson, J. R., Turner, K., Vira, B., Willcock, S. and Birch, J. C. (2013) TESSA: A toolkit for rapid assessment of ecosystem services at sites of biodiversity conservation importance. Ecosyst. Servs. 5: $\mathrm{E}_{51}-\mathrm{E}_{57}$.

Peh, K. S.-H., Balmford, A. P., Birch, J. C., Brown, C., Butchart, S. H. M., Daly, J., Dawson, J., Grey, G., Hughes, F. M. R., Mendes, S., Millett, J., Stattersfield, A. J., Thomas, D. H. L., Walpole, M. and Bradbury, R. B. (2014) Potential impacts of invasive alien species on ecosystem services provided by tropical a forested ecosystem: a case study from Montserrat. Biol. Invasions 17: 461-475.

Peh, K. S.-H., Thapa, I., Basnyat, M., Balmford, A. P., Bhattarai, G. P., Bradbury, R. B., Brown, C., Butchart, S. H. M., Dhakal, M., Gurung, H., Hughes, F. M. R., Mulligan, M., Pandey, B., Stattersfield, A. J., Thomas, D. H. L., Walpole, M. and Birch, J. C. (2016) Synergies between biodiversity conservation and ecosystem service provision: Lessons on integrated ecosystem service valuation from a Himalayan protected area in Nepal. Ecosyst. Servs. 22: 359-369.

Plantlife (2010) Important Plant Areas around the world: Target 5 of the CBD Global Strategy for Plant Conservation. Salisbury, UK: Plantlife International.

Ramírez, I., Geraldes, P., Meirinho, A., Amorim, P. and Paiva, V. (2008) Áreas importantes para as aves marinhas em Portugal (important areas for seabirds in Portugal). Lisbon, Portugal: Sociedade Portuguesa Para o Estudo das Aves.

Ramírez, I., Tarzia, M., Dias, M., Burfield, I., Ramos, J., Garthe, S. and Paiva, V. (2017) How well is the EU protecting its seabirds? Progress in implementing the Birds Directive at sea. Mar. Pol. 81: doi: 10.1016/j. marpol.2017.03.034.

Rands, M. W., Adams, W. M., Bennun, L., Butchart, S. H. M., Clements, A., Coomes, D., Entwistle, A., Hodge, I., Kapos, V., Scharlemann, J. P. W., Sutherland, W. J. and Vira, B. (2010) Biodiversity conservation - challenges beyond 2010. Science 329: 1298-1303.

Rodrigues, A. S. L. et al. (2004) Effectiveness of the global protected area network in representing species diversity. Nature 428 : 640-643.

Skov, H., Durinck, J., Leopold, M. F. and Tasker, M. L. (1995) Important Bird Areas for seabirds in the North Sea. Cambridge, UK: BirdLife International.

Skov, H., Vatikus, G., Raudonikis, L., Sidlo, P. O., Kalamees, A, Luigijze, L., Stipneice, A., Welander, B., Kondratyev, A., Grishanov, G., Scheller, W., Struwe-Juhl, B., Leivo, M., Flensted, K. N. and Rasmussen, J. F. (2000) Inventory of coastal and marine Important Bird Areas in the Baltic Sea. Cambridge, UK: BirdLife International.

Soanes, L. M., Bright, J. A., Angel, L. P., Arnould, J. P. Y., Bolton, M., Berlincourt, M., Lascelles, B., Owen, E., Simon-Bouhet, B. and Green, J. A. (2016) Defining marine important bird areas: Testing the foraging radius approach. Biol. Conserv. 196: 69-79.

Stattersfield, A. J., Crosby, M. J., Long, A. J. and Wege, D. C. (1998) Endemic Bird Areas of the world: Priorities for biodiversity conservation. Cambridge UK: BirdLife International.

Sullivan, B. L., Aycrigg, J. L., Barry, J. H., Bonney, R. E., Bruns, N., Cooper, C. B., Damoulas, T., Dhondt, A. A., Dietterich, T., Farnsworth, A., Fink, D., Fitzpatrick, J. W., Fredericks, T., Gerbracht, J., Gomes, C., Hochachka, W. M., Iliff, M. J., Lagoze, C., La Sorte, F. A., Merrifield, M., Morris, W., Phillips, T. B., Reynolds, M., Rodewald, A. D., Rosenberg, K. V., Trautmann, N. M., Wiggins, A., Winkler, D. W., Wong, W.-K., Wood, C. L., Yu, J. and Kelling, S. (2014) 
The eBird enterprise: An integrated approach to development and application of citizen science. Biol. Conserv. 169: 31-40.

Sydeman, W. J., Piatt, J. F., Browman, H. I. (2007) Seabirds as indicators of marine ecosystems. Mar. Ecol. Process. Ser. 352:199-309. Tracewski, L., Butchart, S. H. M., Donald, P. F., Evans, M., Fishpool, L. D. C. and Buchanan, G. M. (2016) Twenty-first century forest loss across a global network of important sites for biodiversity. Remote Sensing Ecol. Conserv. 2: 37-44.

Tushabe, H., Kalema, J., Byaruhanga, A., Asasira, J., Ssegawa, P., Balmford, A., Davenport, T., Fjeldså, J., Friis, I., Pain, D., Pomeroy, D., Williams, P. and Williams, C. (2006) A nationwide assessment of the biodiversity value of Uganda's Important Bird Areas network. Conserv. Biol. 20: 85-99. van der Sluis, T., Foppen, R., Gillings, S., Groen, T., Henkens, R., Hennekens, S., Huskens, K., Noble, D., Ottburg, F., Santini, L., Sierdsema, H., van Kleunen, A., Schaminee, J., van Swaay, C., Toxopeus, B., Wallis de Vries, M. and Jones-Walters, L. (2016). How much Biodiversity is in Natura 200o?; The "Umbrella Effect" of the European Natura
2000 protected area network. Wageningen, The Netherlands: Alterra Wageningen UR (University \& Research Centre), Alterra report $2730 \mathrm{~B}$.

van Swaay, C. A. M. A. and Warren, M. S. (2006) Prime Butterfly Areas of Europe: an initial selection of priority sites for conservation. Insect Conserv. 10: 5-11.

Waliczky, Z., Fishpool, L. D. C., Butchart, S.H.M.,Thomas, D., Heath, M.F., Hazin, C. Donald, P. F., Kowalska, A., Dias, M. P. and Allinson, T. S. M. (in press) Important Bird and Biodiversity Areas (IBAs): the impact of IBAs on conservation policy, advocacy and action. Bird Conserv. Internatn. doi:10.1017/ So959270918000175.

Wings Over Wetlands UNEP-GEF AfricanEurasian Flyways Project (2011) The Critical Site Network: Conservation of internationally important sites for waterbirds in the AfricanEurasian Waterbird Agreement area. Ede, The Netherlands and Cambridge, UK: Wetlands International and BirdLife International.

WWF and IUCN $(1994,1995,1997)$ Centres of plant diversity. A guide and strategy for their conservation. 3 Vols. Cambridge, UK: IUCN.

PAUL F. DONALD*, LINCOLN D. C. FISHPOOL, LEON A. BENNUN ${ }^{+}$, GILL BUNTING, IAN J. BURFIELD, STUART H. M. BUTCHART, SOFIA CAPELLAN, MICHAEL J. CROSBY, MARIA P. DIAS, MICHAEL I. EVANS, RICHARD GRIMMETT, MELANIE HEATH, VICTORIA R. JONES, BENJAMIN G. LASCELLES, JENNIFER C. MERRIMAN, IVÁN RAMÍREZ, DAVID C. WEGE

BirdLife International, David Attenborough Building, Pembroke Street, Cambridge CB 43 QW, UK. +Present address: The Biodiversity Consultancy, 3 King's Parade, Cambridge CB2 ISJ, UK.

ADEMOLA AJAGBE

BirdLife International Africa Partnership Secretariat, Terrace Cl, Nairobi City, Kenya.

DAVID DIAZ, ZOLTAN WALICZKY

BirdLife International Americas Partnership Secretariat, Casilla 17-17-717 Quito, Ecuador.

MARK O'BRIEN

BirdLife International Pacific Partnership Secretariat, 1o MacGregor Road, Suva, Fiji.

*Author for correspondence; e-mail: paul.donald@birdlife.org

Received II July 2017; revision accepted 26 February 2018; Published online 23 October 2018 